\title{
Language of the Gothic Woman:Jane Campion's The Piano
}

\author{
Eunjin Choi \\ Research Institute of Image and Cultural Content, \\ Dongguk University, Seoul, South Korea
}

\begin{abstract}
Jane Campion's <The Piano> is a well-known film for a number of reasons, such as for being an Oscar winner, for having been helmed by an emerging director from New Zealand, and for having the reputation of being a feminist film. In this paper, the first scene of <The Piano > was chosen to examine the heroine Ada's language in terms of the gothic genre. Ada is a dumb woman who lives in the era of man's language. She represents the women's social position in the Victorian era but has her own and unique language for communicating with the outside world. The first scene of <The Piano> introduces Ada's own language, using her fingers. Her fingers speak for her all the time instead of her mouth, and there is someone who can understand what she wants to say when all others cannot. How the film depicts Ada's language and how the first scene well summarizes the film's core are examined herein.
\end{abstract}

Keywords: <The Piano>, language, finger, gothic genre, feminist film

\section{INTRODUCTION}

Movements and sounds are fundamental elements of films. Of course, a shot may seem to have no movement or sound but actually still has these, albeit silent. As the early films featured only movements, most of the filmmakers then added live music during the films' screening. This was due to technical reasons, and they promptly applied sounds to films after the invention of the sound film. Movements and sounds are basic in the real world as well. All humans make movements and sounds as a matter of course. From a sociologic viewpoint, however, these questions may arise: Who makes movements and sounds, and how do they make these?

In the traditional society, language belonged to men, and women belonged to the men's language. Language is the tool used by mankind for communicating, but the women were excepted from communicating with the men as the men did not regard the women as objects of communication. The men who had language had power, authority, and reason, but the women who had language did not. The women who were someone's mother, wife, and/or daughter were the properties of the men. The men could order the women around, and the women had to obey them. The men also restrained the women's freedom of action and did not give them the right to speak. The women had no voice in any matter, like Ada in the movie The Piano.

The movie The Piano is set against the backdrop of New Zealand in the 1850s. Ada, the main character, lives at the time when the women did not have a voice of their own. This means that the women then could not speak out their thoughts openly

\footnotetext{
*Corresponding author. E-mail : letresor@empas.com Manuscript received Jul 25, 2011 ; accepted Aug.27, 2011
}

because the society did not accept those as opinions. Interestingly, Ada does not speak. In the very first scene of The Piano, Ada introduces herself via voice-over narration.

The voice you hear is not my speaking voice, but my mind's voice.

\begin{abstract}
I have not spoken since I was six years old. No one knows why, not even me. My father says it is a dark talent and the day I take it into my head to stop breathing will be my last.

Today he married me to a man I've not yet met. Soon my daughter and I shall join him in his own country. My husband said my muteness does not bother him. He writes and hark this: God loves dumb creatures, so why not he!

Were good he had God's patience for silence affects everyone in the end. The strange thing is I don't think myself silent, that is, because of my piano. I shall miss it on the journey.
\end{abstract}

This concise introduction provides crucial information about Ada and The Piano. In this paper, this opening scene is analyzed in terms of two aspects: audio/Ada's narration and video/Ada's fingers. These two elements of the opening scene explain all about The Piano and Ada.

At this point, an examination of the film's audio/Ada's narration is in order. 


\section{AUDIO/ADA'S NARRATION}

\subsection{Voice}

The voice you hear is not my speaking voice, but my mind's voice.

Ada says that she speaks through her mind's voice and not through her speaking voice. Why does she not speak using her speaking voice?

As was mentioned in the introduction to this paper, Ada lives in the era where women are not allowed to speak. She knows that the women are not allowed to have their own voice. Of course, women can speak, but Ada knows that the society and men do not listen to the women. Ada seems to be a dumb person, but she actually speaks through her mind's voice. Ada does not speak, but she has her own unique ways of "speaking": playing the piano and employing the sign language. She uses these as intended: the piano for emotional expression and the sign language for communication. She uses finger movements rather than her voice to communicate something. She chooses the language of movement, which her lover can hear and understand, rather than the spoken language that other people do not actually listen to.

Ada uses the aforementioned two methods to "speak," which makes her unique. Everyone in her world uses his/her voice to speak and communicate, but she does not make any sound through her mouth. Instead of making sounds, she executes movements with her fingers. The opening scene of The Piano gives a hint about her own language with the use of her fingers. Ada is shown covering her eyes with, and seeing the world through, her fingers. She then talks about herself through her mind's voice. She speaks using her inner voice while seeing through her fingers. This scene shows Ada using her fingers when saying something.

Ada plays the piano with her beautiful finger movements and speaks through the sign language, with her thin arms and fingers. Despite these, it is noteworthy that she is the most independent and strong-willed woman in this film. This author believes that the film's director, Jane Campion, wanted to tell the film's viewers that Ada is not really a dumb person inside. Her inner voice is heard first, after which her language can be seen and heard through her fingers.

Even though Ada does not make any sound through her mouth, she speaks all the time through her own language, using her fingers and her mind's voice.

\subsection{Dark Talent}

I have not spoken since I was six years old. No one knows why, not even me. My father says it is a dark talent and the day I take it into my head to stop breathing will be my last.

Ada says that she does not speak by her own will, and that her father says that this is her dark talent. The first two sentences above will first be focused on here. There is no clue as to why Ada has not spoken since she was six years old, but the above lines indicate that it was Ada's will not to speak.
There is a huge difference between not being able to speak and not speaking. Ada says that she just started not speaking at age six and that no one knows why it happened. Maybe she just does not want to explain why she does not or could not speak. What is evident is that Ada has not spoken from the time that she decided not to speak through her speaking voice.

The narration is a little girl's voice. This author thinks that this was Ada's voice when she was six years old. It was then that she stopped speaking, so her last memory of her voice is this little girl's voice. This makes her argument convincing, but it is strange to hear a lady's narration in a little girl's voice. The opening and last scenes, however, are the only instances in the film when Ada's voice is directly heard, even though it is the voice of a little girl.

The Gothic atmosphere - gloomy and mysterious - have repeatedly signaled the disturbing return of pasts upon presents and evoked emotions of terror and laughter. [3]

The film's heroine, who does not speak, makes this film a gothic film. The heroine of the film is supposed to be beautiful, attractive, gentle, docile, and obedient, but Ada is a woman who is independent, strong-willed, gloomy, sensitive, passionate, obsessed with the piano, and even does not speak. She is an unusual and abnormal woman, and she has her own world in her mind, distinct from the outside world. It is hard to come close to her, except for her lover George.

Ada's father says that she has a dark talent, and this statement confirms that she is a gothic woman.

What is gothic? ... It typically includes a mysterious and threatening older man, a vulnerable heroine, and a character who is poised ambiguously between good and evil. [3]

In the opening scene of the film, Ada's fingers are first shown, and then the viewers see what Ada looks like. She has a pale bare face and wears a black dress, a signature Victorian clothing item. In this film, Ada always wears a laced-up corset, huge hoop skirts, pantaloons, a chemise, a petticoat, and a bodice. She is always shown wearing a black dress, which makes her small body look even smaller. She looks like she is wary of other people, like a timorous little bird, and has compressed lips.

The mise en scene of The Piano is filled with gothic energy as a nonorganic life animating things. The most remarkable gothic mise en scene is the piano. Ada identifies herself with the piano. She came to New Zealand with her piano as her alterego. She is obsessed with the piano and feels most comfortable when she is playing it. This massive black thing makes her frustrated and relaxed, like a lover. This strong bond between Ada and the piano, however, may look strange to other people. A dumb person who is obsessed with the piano looks bizarre.

Normally, the setting of a gothic film is a remote castle in a deep, dark forest. In The Piano, however, it is the remote country New Zealand. 
... they call it an "Australian gothic," which they see as "a genuinely local aesthetic tendency and one that has had some vitalizing effects on the industry.” [9]

The Piano was transformed from a castle in Europe into a remote village in New Zealand. Stewart, Ada’s husband, lives far away from civilization. The village people are immigrants mostly from England, and they intermingled with the Maoris. This town is located in the inland of New Zealand, far from the seashore. Ada has trouble moving the piano from the seashore to her house. Her alterego, the piano, is thus left on the seashore at first and is then moved to George's house and then finally to her place. This shows that Ada came to a land that does not allow her to do something by her own decision.

A woman with her daughter and the piano come to the isolated place. A wild, bleak, and beautiful landscape completes the Australian gothic.

\subsection{Marriage}

Today he married me to a man I've not yet met. Soon my daughter and I shall join him in his own country. My husband said my muteness does not bother him. He writes and hark this: God loves dumb creatures, so why not he!

Ada is a single mother in the 1850s. It is not known what her first marriage was like. What is known about it is only that her ex-husband was kind to her on account of her muteness. Flora, Ada's daughter, once tells their maid about her father, but she actually only made up the story. What is interesting is that the director, Jane Campion, put short animation at the end of the film. Flora said that her German-musician father was killed by lightning and fire in the forest, and a man in flames is shown. Flora's story seems absurd, but this is the only part of the film that reveals information on Ada's previous marriage. According to Flora's story, Ada and her ex-husband had a happy marriage and both loved music. Their marriage ended due to a terrible accident, which made Ada stop speaking.

After being widowed, Ada has to go to a foreign country to marry a man whom she has never ever met before, as arranged by her father. This is the destiny of the women who lived in the 1850s. They belonged to the men in their lives, such as their father or husband. What a woman was to do with her life was decided by the man and not by herself. Ada goes to New Zealand due to the unfair decision of her father, but she keeps her attitude to herself. She knows what she wants and what she does not want. She wants a man who can communicate with and understand her, which, according to her, her ex-husband was. Even if he quoted "God loves dumb creatures," he seemed to know that the communication between two people is not limited to spoken language. If he was indeed a musician, as claimed by Flora, then he must have understood the language of the piano.

Ada and Flora come to the shores of New Zealand, which does not look like a place for the piano. What is worse, she meets Stewart, her husband-to-be, who tells him that they cannot move the piano inland. Ada insists on doing so, but
Stewart does not really care about Ada or what she wants. This situation continues well into the film. Ada says something to Stewart, but he does not accept her opinions, thoughts, or feelings. At times, Stewart is afraid of Ada's dark talent. George, however, has a different attitude towards Ada. He is not afraid of her dark talent and even tries to get to know Ada through her own way of communicating. Ada's muteness does not bother George, who listens to Ada's music.

My husband said that my muteness does not bother him. He writes and harks this: God loves dumb creatures, so why not he?!

In the above lines, Ada is actually talking about her exhusband, but she may as well be talking about George. Her actions seem to be dictated by men, but she eventually gets what she wants and what she needs in marriage.

\subsection{The Piano}

Were good he had God's patience for silence affects everyone in the end. The strange thing is I don't think myself silent, that is, because of my piano. I shall miss it on the journey.

A dumb person is supposed to be silent. Ada is a silent person, but she does not think that she is, because of her piano. This narration shows that Ada keeps saying something about herself in light of her piano. The problem is not many people know the fact that her piano is her other self. Her act of leaving her piano on the seashore signifies her realization that Stewart is not the right man for her.

The piano is a big deal to Stewart as well. He did not know that Ada would bring the piano to New Zealand. To him, the piano is just a massive and heavy musical instrument; he could not attach any meaning to such nuisance. Stewart wants Ada to be a good wife and to focus on their new marriage and family, but Ada does not care about Stewart's interests and is obsessed with the piano. Her obsession with the piano makes Stewart notice her dark talent. Especially, the scene where Ada plays the piano in her sleep shows Ada as a gothic woman.

However George accepts Ada's dark talent. He is tolerant of the ways of other people, intermingling with the Maoris and learning their language. He knows how to accept other people the way they are. When George meets Ada, he observes her closely and figures out how to communicate with her. This is the difference between the two men. After George gets to know Ada, he becomes attracted to her dark talent. This is his difference from Stewart.

The film's director chose the piano as Ada's alterego, and it worked. The piano is one of the heaviest and biggest musical instruments, and it requires one to make splendid finger movements. Ada has a petite physique or body frame, but her inner world is bigger than that of any other character in this film. She has a strong will and is hard to persuade, and its weight is as heavy as the piano. Moreover, Holly Hunter, who plays Ada in the film, plays the piano herself, showing her splendid and beautiful finger movements to the film's viewers. In many ways, the piano is a good prop for showing Ada's 
character.

An analysis of the video/Ada's fingers in the opening scene is now in order.

\section{VIDEO/ADA'S FINGERS}

The opening scene of a film is regarded as important because it is the first part of the film to be shown to the viewers. It introduces the film to the viewers and forms their first impression of it, which The Piano does. The opening scene of The Piano zeroes in on Ada's fingers. Ada is covering her eyes with her fingers and is looking at the world through them. Then she talks about herself through her mind's voice and not through her speaking voice. She says that she has not spoken since the age of six, and she emphasizes that this was by her own will. This scene shows the viewers crucial information about Ada, the film's heroine. She speaks through her inner voice and sees through her fingers. Most people use their mouth to say something, but this opening scene shows Ada using her fingers to do so.
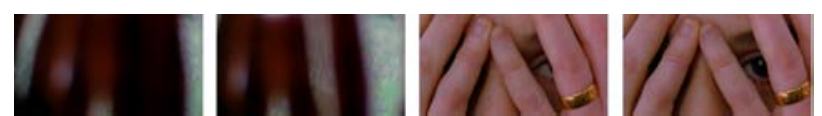

Fig 1. <Ada is looking through her fingers.>

\subsection{Piano and the Sign Language}

Ada has two methods of communication: through the piano and through the sign language. First, she expresses her emotional state through the piano, through which she can freely release her repressed passions. She is shown to be obsessed with the piano because she communicates with the world through it, in her own way. She uses her fingers to play the piano; the movements of her fingers are sweet, mellow, deep, and dark but sometimes furious. When she is locked up in the house by her husband, she plays the piano in her sleep. It can be said that she says something through her fingers, while subconsciously playing the piano. Moreover, she wears fingerless gloves in most of the film's scenes, so her fingers are quite notable.

The second way by which Ada communicates is through the sign language. Flora, Ada's daughter, is the only other character in the film who knows the sign language, so she becomes Ada's spokesperson. Almost at all times, Ada is with Flora and Flora speaks instead of Ada. The sign language consists of movements of the fingers and arms for communication purposes. When Ada says something using the sign language, her mouth does not make any sound, but her fingers make many movements. At times, she writes what she wants to say on a piece of paper, but only in emergency cases. Interestingly, George, Ada's lover, cannot read but can hear the sound of the piano. Conversely, Stewart, Ada's husband, can read but cannot hear his wife's inner voice through the piano.

\subsection{Touch}

Ada uses her fingers not only to communicate but also to feel. She does not just touch the piano keys to play the piano. She touches the piano keys with the back of her fingers, as if touching her lover. It seems that the time that she spends playing the piano is her own time to feel her emotions. On the night that Ada and Flora land on the beach of New Zealand by themselves, Ada puts her hand into the piano's container. She then plays the piano, and the camera zeroes in on her hand. She seems to restore her stability by playing the piano. After a long while, George gives back the piano to Ada, but Ada does not look happy. She ponders her relationship with George and then touches the piano keys with the back of her fingers. She feels George by touching the piano. Moreover, she feels the seawater with her fingers when Ada, George, and Flora leave the town by boat. She immerses her fingers into the seawater and waves her hand gently, then throws herself with the piano into the water, as if she and the piano are one person. She touches not only objects but also men, but the way that she touches one of the two men in her life is different from how she touches the other.

The second time that Ada comes to George's house to give him a piano lesson, George suddenly touches the back of her neck. She is frightened by his touch, but he makes a deal with her, in which she can get back the piano if she will allow him to touch her in each of their piano lessons. George tries to touch her in a strange way; like Ada, he uses his fingers. He touches her leg through a hole on her stocking, using his fingertip, and he touches her arms with his fingers. When he is alone with the piano, he touches the piano and wipes it with his clothes. This scene shows how George treats Ada through how he treats the piano. At first, Ada is on her guard against George, but she decides to go ahead and love him afterwards.

\subsection{Husband and Lover}

Stewart, however, tries to get closer to Ada through words and not through touch, even if she does not speak. He keeps asking the other women working at his house about Ada. He has no idea about Ada's own language and does not want to know about it. When George gives the piano back to Ada, Stewart thinks that Ada will be happy, but Ada's response is the opposite of what he expected. She goes out of the house and wanders in the courtyard with a somber look on her face. He makes Flora play the piano and slaps the piano to the beat of the song. This is how Stewart treats Ada, which is exactly the opposite of how George treats her. He regards Ada as his property and sees her as capable of becoming a good wife someday. While confined by Stewart to his house, Ada touches Stewart's face and body, but her touch is unilateral: she touches, and he is touched. This shows that their relationship is onesided. After he finds out about Ada's relationship with George, Stewart starts to use his power and even resorts to violence. Stewart is enraged by his wife's affair and chops off Ada's trigger finger with an axe, leaving only a stump. He punishes Ada by damaging her tool for expression and communication, and threatens her with further punishment. In the last sequence of the film, however, George fashions Ada a metal fingertip, which enables her to play the piano again, with the new sound of tapping between the piano keys and her metal fingertip. Her husband hurts her, but her lover cures her.

Ada is supposed to be Stewart's wife, but she shares her language with George, her lover. Ada, realizing that George is the one who can understand her language of fingers, chooses 
him. Perhaps Ada and George share a secret that nobody else knows.

\section{CONCLUSION}

After seeing this film several times, this author found the opening scene as containing almost everything about the film, and found that it works. This means that the director and writer of The Piano, Jane Campion, shot this scene with great effort. This scene is a good introduction of the film's heroine through a concise voice-over.

The Piano is an interesting text to read for many reasons, on account of its genre, gender, music, language, acting, movement, costume, landscape, history, sociology, mise en scene, etc. What is interesting is that this film was given a nickname that means "an Australian gothic film" as it is a gothic film in Europe that moved to New Zealand and that was transformed into a new, evolved genre. The old castle in the deep forest becomes an isolated island in New Zealand, but there is still a woman with a dark talent. This gothic woman finally gets what she wants, and its film's director got the much-coveted Best Director award in the 1993 Cannes Film Festival.

\section{REFERENCES}

[1] Campion, Jane. The Piano. Bloomsbury, 1993.

[2] Hendershot, Cyndy. (Re)Visioning the Gothic: Jane Campion's The Piano, Film Quarterly, 1998.

[3] Hopkins, Lisa. Screening the Gothic. University of Texas Press, Austin, 2005.

[4] Jayamanne, Laleen. Postcolonial Gothic: the narcissistic wound of Jane Campion's The Piano. 2001.

[5] Kuhn, Annette. Women's Pictures. Verso, 1982.

[6] Mayer, Geoff. Beattie, Keith. The Cinema of Australia and New Zealand. Wallflower, 2007.

[7] Spooner, Catherine. Fashioning Gothic Bodies. Manchester University Press, 2004.

[8] Williams, Gilda. The Gothic. Whitechapel, 2007.

[9] 2BL, Australian Broadcasting Corporation, 24 March 1992.

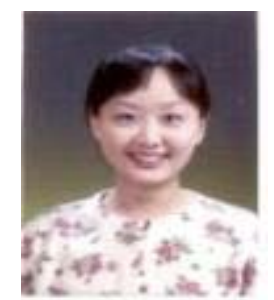

\section{EUNJIN CHOI}

She received a Bachelor of Arts degree, major in French Language and Literature and English Language and Literature from Seoul Women's University in South Korea in 2003, and received a Master of Arts degree in Film Studies from Dongguk University in South Korea in 2006. She also received a Master of Film and Digital Image degree from the University of Sydney in Australia in 2011 and has completed the doctoral coursework in Film Studies at Dongguk University. Since then, she has been with the Research institute for Image \& Cultural Contents in Dongguk University. Her main research interests include film critique and digital-film production. 